(d) JPSI

E-ISSN: $2622-1837$

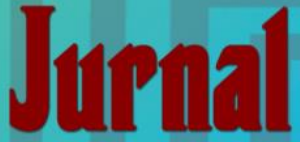

Pendidikan Sejarah Indonesia

\section{KONSEPSI TRIPRANGAMA UNTUK MENANAMKAN KESADARAN HUKUM DALAM PEMBELAJARAN IPS MELALUI PEDAGOGI REFLEKTIF}

\author{
Listyanto Aji Nugroho*, Sariyatun \\ lisyantoajinugroho@student.uns.ac.id
}

\section{Prodi Pascasarjana Pendidikan Sejarah, Universitas Sebelas Maret, Indonesia}

Abstract: Legal awareness is an important value for the nation building. The legal awareness of Indonesian people is indicated below average. Supposed to make advancement, every people of Indonesian should have a high level of legal awareness. Education offers a solution for this problem. By engaging in education, students are expected to enhance their legal awareness. Using reflective pedagogy paradigm, this study assumed that student can be engaged to contemplate themselves, are they law-abiding citizens? Using a concept of ancient Triprangama law, students are persuaded to cultivate legal awareness though social studies education. The aim of this article is to describe the learning concept to promote the legal awareness of student with social studies subject matter that integrated with Triprangama concept with reflective pedagogy approach.

Keywords: legal awareness, social studies, triprangama

\title{
PENDAHULUAN
}

Pada hakikatnya manusia adalah mahluk sosial, tidak pernah bisa lepas dari manusia lainnya. Dalam setiap pranata kehidupan, akan selalu terjadi interaksi dan hubungan saling membutuhkan antar manusia. Perbedaan paradigma, pemikiran kebutuhan, dan kepentingan seringkali menyebabkan gesekan-gesekan hingga konflik antara manusia. Tidak jarang konflik-konflik ini meluas dan menimbulkan rusaknya tatanan kehidupan. Pada tahapan ini maka diperlukan seperangkat aturan yang disepakati bersama untuk mencegah terjadinya kerusakan tatanan kehidupan yang disebut sebagai hukum. 
Hukum diharapkan menjadi acuan/pedoman bagi masyarakat untuk melakukan tindakan apapun dalam kesehariannya. Peran hukum menjadi sangat vital dalam konteks bermasyarakat untuk terwujudnya masyarakat yang berkeadilan dan setara. Melalui hukum, keutuhan suatu tatanan kehidupan sebagai sebuah sistem sosial akan terjaga dengan baik (Rosana, 2014: 1-2). Namun demikian, tidak semua orang menganggap penting dan mau menaati hukum yang berlaku. Terkadang aturan-aturan hukum dianggap tidak sesuai dengan kepentingan-kepentingan orang tertentu. Dalam sudut pandang humanistik, aturan-aturan hukum ini terkadang tidak memiliki meaning atau makna bagi individu tertentu sehingga individu tersebut merasa bahwa hukum tidak relevan dan tidak perlu ditaati. Di sinilah perlunya untuk mendekatkan meaning dari hukum sehingga orang akan merasa bahwa hukum adalah relevan dengan kehidupannya (Qodir, 2017).

Proses mendekatkan meaning dari hukum kepada individu ini dapat diukur melalui tingkat kesadaran hukum. Peranan dari kesadaran hukum sendiri adalah untuk menanamkan rasa kesadaran dan pentingnya memahami dan menaati hukum agar tidak terjadi kekacauan dalam sistem sosial yang ada. Kesadaran hukum perlu untuk dipupuk sedari dini dalam pemahaman masyarakat agar hukum senantiasa dipatuhi setiap saat.

Peserta didik memiliki tugas sebagai agen perubahan sosial dan agen kontrol sosial dalam masyarakat. Peserta didik merupakan suatu subsistem dalam masyarakat dengan pemikiran kritis terhadap pelaksanaan hukum. Dalam keadaan tertentu, peserta didik dapat menjadi penggerak bagi perubahan arah hukum dan demokrasi di masyarakat (Kenedi, 2015: 206). Beranjak dari permasalahan bangsa di bidang hukum dewasa ini, peran serta peserta didik untuk terus mengkritisi dan mengawasi berjalannya hukum menjadi sangat vital di masa kini saat hukum mulai tererosi sedikit demi sedikit. Untuk itu maka perlu ditanamkan kesadaran hukum sebaik mungkin dalam diri peserta didik. Upaya ini dapat diwujudkan melalui pendidikan, karena pendidikan merupakan alat propaganda dalam penanaman nilai dan karakter yang paling efektif (Widja, 2002: 75). Upaya ini merupakan bagian dari Penguatan Pendidikan Karakter (PPK) sesuai amanat Perpres No 87 Tahun 2017 yang bertujuan untuk membangun dan membekali peserta didik sebagai generasi emas Indonesia Tahun 2014 (Sekretariat Negara Republik Indonesia, 2017). Namun kembali lagi mengacu pada Perpres 87, pendidikan karakter belum menyasar pada penanaman kesadaran hukum. Pada pasal 3, karakter yang ditanamkan dalam PPK meliputi: “... religiositas, kejujuran, teleransi, kedisiplinan, kerja keras, kreatif, mandiri, demokratis, keingintahuan, semangat kebangsaan, cinta tanah air, menghargai prestasi, komunikatif, cinta damai, gemar membaca, peduli lingkungan, dan bertanggungjawab". Saat ini tren pengembangan pendidikan masih berpilar nilai-nilai tersebut (Rochmawat, 2017: 42) dan belum ada secara spesifik mengenai kesadaran hukum. Untuk itu, dirasa perlu untuk dikembangkan suatu desain pembelajaran yang mengakomodir penanaman karakter peserta didik yang sadar hukum. Peristiwa sejarah dalam konteks Pendidikan IPS memiliki peluang untuk dieksplorasi kembali menjadi bahan pembelajaran nilai-nilai kesadaran hukum.

Peristiwa-peristiwa sejarah dapat digunakan sebagai acuan dalam menanamkan nilai-nilai dan konsepsi-konsepsi pada peserta didik di masa kini. Berkaitan dengan penanaman kesadaran hukum 
pada peserta didik, maka perlu didesain suatu pembelajaran yang memiliki konten-konten peristiwa sejarah yang berkaitan dengan fenomena-fenomena hukum. Beberapa peristiwa yang dapat dijadikan konten adalah: peristiwa pengadilan, sengketa hukum, penindakan hukum, hingga peristiwa pelanggaran hukum. Salah satu yang dapat digunakan adalah peristiwa-peristiwa hukum yang terjadi di masa Jawa kuno, lebih tepatnya pada masa Mataram kuno pra Kahuripan. Pada masa ini belum ditemukan kitab-kitab hukum, namun proses peradilan menggunakan konsepsi Triprangama yang terdiri atas likitha, sakshi, dan bhukti. Peristiwa-peristiwa hukum yang terjadi banyak tercatat dalam prasasti-prasasti. Salah satu raja yang banyak mengeluarkan prasasti, terutama prasasti yang berisi ketetapan hukum dan proses hukum melalui Tripranggama adalah Raja Balitung (Boechari, 2012: 192).

Konsepsi ini dapat dikaji bersama dengan peserta didik untuk kemudian dimaknai kembali oleh peserta didik dalam kehidupan sehari-harinya. Untuk tingkatan sekolah menengah pertama konsepsi ini merupakan bagian dari pembelajaran sejarah, dimana pembelajaran sejarah merupakan suatu disiplin ilmu yang terintegrasi ke dalam pembelajaran Ilmu Pengetahuan Sosial (IPS). Pendidikan IPS terdiri dari berbagai disiplin ilmu sosial dan humaniora yang diintegrasikan menjadi satu kemasan dalam tujuan pendidikan. Pendidikan IPS memiliki fungsi untuk membantu peserta didik secara optimal mengembangkan kemampuan dalam menghadapi berbagai persoalan di masyarakat. Secara khusus, tujuan dari pembelajaran IPS adalah: (1) mengenalkan konsep dalam kaitan kehidupan masyarakat dan lingkungan; (2) memberikan kemampuan berfikir kritis dan logis, keingintahuan tinggi, memecahkan permasalahan sosial; (3) berkomitmen dan sadar akan nilai-nilai sosial; (4) berkemampuan komunikasi, kompetitif, dan mampu bekerjasama (Syaputra \& Sariyatun, 2020). Salah satu ilmu sosial yang terintegrasi dalam IPS adalah ilmu Sejarah.

Melalui pembelajaran IPS dengan pengayaan materi tentang konsep hukum triprangama pada masa kerajaan Mataram Kuno, diharapkan para peserta didik dapat memiliki kesadaran hukum yang lebih baik lagi. Penanaman nilai-nilai kesadaran hukum ini perlu dilakukan dengan paradigma pedagogi reflektif yang dirasa sangat sesuai untuk menanamkan nilai-nilai yang berkaitan erat dengan kehidupan sehari-hari melalui pemaknaan dan refleksi materi yang relevan dengan kehidupan sehari-hari. Dari segi bahan ajar, sangat disarankan untuk menggunakan bahan ajar digital. Bahan ajar digital akan membuat pembelajaran menjadi menarik, mudah dipahami, dan lebih beragam. Bahan ajar digital juga sangat efisien untuk digunakan terutama pada era 4.0 seperti saat ini (Sariyatun, Joebagio, \& Akhyar, 2018).

Untuk itu, tulisan ini bertujuan untuk memaparkan suatu konsep pembelajaran yang berfungsi untuk meningkatkan kesadaran hukum peserta didik melalui pembelajaran IPS yang diintegrasikan dengan konsepsi Triprangama dalam pendekatan pedagogi reflektif. Diharapkan konsep ini kedepannya dapat dieksplorasi lebih dalam lagi dan diimplementasikan dengan baik. 


\section{PEDAGOGI REFLEKTIF}

Pedagogi reflektif atau juga disebut dengan pedagogi Ignatian merupakan suatu pemikiran yang mencoba untuk menumbuhkembangkan pribadi peserta didik untuk lebih memanusiakan manusia. la merupakan suatu paradigma yang diperkenalkan oleh kelompok religious yang bernama Serikat Jesuit sejak 1548 (Subagya, 2010: 7). Oleh pendirinya yaitu Ignatius Loyola, Pedagogi Reflektif ditujukan sebagai proses kolaboratif antara pendidik dan peserta didik dimana inkuiri, kreatifitas, discovery, dan refleksi/kontemplasi membantu meningkatkan kemampuan personal dan profesional (Pousson \& Myers, 2018: 3). Pedagogi reflektif dapat digunakan dalam konteks pembelajaran unuk mendorong terjadinya reformasi politik dan sosial dalam masyarakat (Reardon \& Snauwaert, 2011: 14). Pedekatan pembelajaran ini berfokus pada pengalaman belajar peserta didik untuk memberikan kesempatan mengidentifikasi signifikansi dan makna dari pengalaman belajar yang diberikan (McGuire, Lay, \& Peters, 2009: 94). Dengan pedagogi reflektif, gambaran manusia yang ideal diharapkan akan dapat dicapai. Pendidikan diharapkan menciptakan peserta didik yang lebih "utuh" sebagai seorang manusia yang mampu untuk membawa perubahan masyarakat ke arah yang lebih baik.

Sebagai suatu prosedur pembelajaran, pedagogi reflektif berisi interaksi peserta didik dengan materi yang diberikan dan pendidik sebagai fasilitatornya. Proses pembelajaran dirancang sedemikian rupa agar peserta didik menjadi pusat proses belajar dan mampu menemukan kesadarannya sendiri untuk menggali pengetahuan serta nilai-nilai dengan penuh tanggung jawab. Tidak hanya sekedar pengetahuan kognitif saja, namun juga diharapkan dapat mengembangkan kemampuan berfikir dan bertindak, hati nuraninya, serta kehendak untuk berbela rasa dengan orang lain (Suparno, 2015: 5). Dalam pelaksanaan pedagogi reflektif, terdapat lima langkah yang berkesinambungan, yaitu: konteks, pengalaman, refleksi, aksi, evaluasi (Pousson \& Myers, 2018: 5; Subagya, 2010: 43).

\section{Konteks}

Konteks adalah keadaan awal peserta didik dalam suatu proses pembelajaran. Kehidupan sehari-hari peserta didik menjadi starting point proses. Dalam pedagogi reflektif konteks dimulai dari kehidupan sehari-hari peserta didik (Subagya, 2010: 43). Konteks ini berada dalam tiga tataran: sistem mikro, sistem meso, dan sistem makro. Sistem mikro merujuk pada latar belakang peserta didik, seperti keluarga, komunitas, ekonomi, budaya, sistem kepercayaan, dan berbagai variabel lain yang dapat memengaruhi pembelajaran. Sedangkan didalam sistem meso terdapat berbagai macam lingkungan belajar seperti: sekolah, universitas, akademi. Sangat penting untuk mengidentifikasi bagaimana lingkungan belajar memengaruhi iklim belajar. Dan pada tataran sistem makro terdapat konteks tentang sosial ekonomi, politik, dan elemen-elemen budaya yang mempengaruhi bagaimana tumbuh kembang peserta didik (Pousson \& Myers, 2018: 3). Dengan mengetahui konteks awal peserta didik, pendidik dapat mengetahui bagaimana kondisi awal peserta didik seperti: berbagai latar belakang, iklim belajar peserta didik, gaya belajar, hingga perasaan peseta didik. 
Selanjutnya pendidik dapat memutuskan untuk memperlakukan peserta didik dengan cara yang ideal sesuai kondisi masing-masing peserta didik.

\section{Pengalaman}

Pendidikan melalui suatu pengalaman memberikan kesempatan bagi peserta didik untuk belajar melalui pengalaman didalam dan diluar kelas (Rocheleau, 2004). Pengalaman merupakan komponen yang sangat penting dalam konteks pedagogi reflektif. Berkaitan dengan pengalaman, pendidik memiliki posisi sebagai fasilitator dalam pembelajaran. Hati, perasaan, pikiran, dan pribadi peserta didik akan dilibatkan dalam pengalaman belajar (Subagya, 2010: 49-50). Pengalaman dapat juga dikatakan sebagai proses untuk menantang dan menghadapkan peserta didik dengan pengetahuan secara seketika. Seorang pendidik harus memiliki kemampuan untuk menggunakan berbagai metode pembelajaran yang memperhatikan pada berbagai gaya belajar, kemampuan, cara memahami, dan latar belakang pengetahuan peserta didik (Pousson \& Myers, 2018: 5). Pengalaman dapat berupa pengalaman langsung maupun pengalaman tak langsung. Pengalaman langsung merupakan proses partisipasi interpersonal peserta didik secara langsung untuk mendapat pengetahuan baru. Sedangkang pengalaman tak langsung, peserta didik menggunakan imajinasinya untuk membayangkan dan merasakan topik yang sedang dibicarakan (Duminiuco, 2000).

\section{Refleksi}

Pengetahuan didapatkan dengan serangkaian proses dimana salah satunya adalah membuat penilaian tentang informasi yang baru saja didapatkan. Penilaian ini melibatkan kegiatan refleksi. Refleksi merupakan proses mendalami kembali pengalaman belajar untuk mendapatkan makna secara mendalam. Berbagai macam pertanyaan-pertanyaan yang diajukan oleh pendidik akan menuntun peserta didik untuk menyelami kembali materi dan pengalaman belajar yang telah diberikan. Peserta didik mendapatkan kesempatan untuk mengintegrasikan aktifitas refleksi dalam kegiatan belajarnya untuk menguatkan dampak dari materi pembelajaran dalam pemahamannya. Aktifitas-aktifitas refleksi dapat dikembangkan oleh para pengajar untuk secara tepat memfasilitasi peserta didik memahami apa makna dari materi pembelajaran (Pousson \& Myers, 2018: 5; Subagya, 2010: 60).

\section{Aksi}

Dengan merefleksikan pengalaman belajar yang telah dilalui, baik aspek kognitif maupun afektif akan menggerakan peserta didik untuk melakukan suatu aksi. Aksi merujuk pada pertumbuhan dari dalam diri peserta didik dalam dua tahapan. Melalui berkembangnya pemahaman kognitif dari pengalaman belajar yang kemudian mempegaruhi afektif peserta didik. pertumbuhan batin peserta didik terjadi ketika peserta didik memutuskan bahwa pengetahuan baru yang didapatkan akan mengklarifikasi nilai-nilai untuk menjadi suatu kebenaran yang memandu pertumbuhan berkelanjutan. Setelah melalui serangkaian proses refleksi terhadap pengalaman belajar, peserta didik akan dihadapkan pada sebuah pertanyaan, "apa selanjutnya yang akan kamu 
lakukan?". Diharapkan untuk ada tindak lanjut dari pertanyaan ini dengan menjadi agen-agen perubahan di masyarakat (Pousson \& Myers, 2018: 6).

\section{Evaluasi}

Proses ini dilaksanakan untuk meninjau efektivitas proses pembelajaran. Dalam pedagogi reflektif, fokus evaluasi harus menyeluruh pada semua aspek pembelajaran untuk mengukur adanya perubahan sikap dan tertanamnya nilai-nilai (Subagya, 2010: 61).

Sintaks-sintaks dalam pedagogi reflektif dirasa tepat untuk menanamkan nilai-nilai dan karakter dalam pembelajaran. Setiap materi pembelajaran akan dapat dimaknai secara pribadi oleh masing-masing peserta didik setelah melalui proses refleksi kontemplatif. Terkait dengan kesadaran hukum, karakter ini dapat ditanamkan dengan suatu proses pembelajaran dengan sintak-sintak pedagogi reflektif untuk mengkaji tentang konsep Triprangama yang tersirat di dalam Prasasti Guntur.

\section{KONSEP TRIPRANGAMA BERDASARKAN ISI PRASASTI GUNTUR}

Kajian ini menggunakan Prasasti Guntur sebagai salah satu pokok kajiannya. Prasasti Guntur ditemukan di Wonosobo Jawa Tengah, saat ini tidak ada catatan mengenai kapan prasasti ini pertama kali ditemukan. Prasasti ini bertuliskan angka tahun 829 Saka atau 907 Masehi dan dikeluarkan oleh Maharaja Dyah Balitung. Prasasti ini di transliterasi atau dialihaksarakan oleh Boechari. Isi prasasti adalah mengenai Jayapattra atau keputusan peradilan, yang lebih spesifik mengenai peristiwa utang piutang. Berikut ini adalah hasil transliterasi dari prasasti Guntur oleh Boechari (2012):

1. swasti śakawarșātīta 829 śrawaṇa māsa tithi dwādaśi śukla. ma. po. bu. wāra tatkāla ni pu tabwěl

2. anagbanua in guntur punpananin wihära garun pinaricchedagunadoșanirade samggat pinapan

3. pu gawul muan san anakabwi pu gallam wanua i puluwatu. sambandha nikan gunadoșa. hana san dharma nara

4. nya bapa ni manhaping sankäri wurakun ya ta tumagiḥ pu tabwěl tinagihakanya mas su 1, nda tan hutan

5. pu tabwěl ya hutan sang anakbwi. Makaniaran si campa. wuan sānak san dharma. pajjah pua si campa. tinagih

6. ta pu tabwěl de san dharma. ndā tan hanānak ni pu tabwěl muan si campa. niuniweh yar wruha rikan hutan ya

7. ta matanyan tka ri samagat pinapan ndà tan tka san dharma rikan pasamayān ya matanyan inalaha

8. ka ta ya de samagat pinapan

Terjemahan bebas prasasti Guntur oleh Listyanto Aji Nugroho (2019): 
1. //o// Selamat tahun Saka yang telah berlalu 829 (tahun), pada hari Rabu Pon, peringkelan Mawulu, tanggal 12 paroterang bulan Srawana ketika pu Tabwel

2. Penduduk Desa Guntur milik bangunan suci di Garung diperkarakan oleh Samgat Pinapan yang bernama

3. Pu Gawul dan istrinya bernama Pu Gallan dari Desa Puluwatu, sebabnya ia diperkarakan, karena Sang Dharma namanya

4. Bapak dari Manghapig dari Desa Wurakung yaitu menagih kepada Pu Tabwel hutangnya sebesar 1 suwarna uang emas.

5. Pu Tabwel tidak mempunyai hutang, hutang itu hutang istrinya yang bernama Si Campa, kepada saudaranya Sang Dharma. Si Campa kemudian meninggal

6. Ditagihlah Pu Tabwel oleh Sang Dharma, apalagi Pu Tabwel tidak mempunyai anak dengan Si Campa, lebih-lebih ia tidak mengetahui mengenai hutang istrinya,

7. Itulah sebabnya datang tuntutan dari Samgat Pinapan. Dalam persidangan Sang Dharma tidak hadir, itulah sebabnya ia

8. Dikalahkan oleh Samgat Pinapan.

Prasasti Guntur memuat suatu ketetapan hasil pengadilan yang dikeluarkan pejabat Samgat Pinapan (Petinggi agama wilayah Pinapan) memenangkan pihak tergugat, Pu Tabwel, dengan perkara utang piutang. Diceritakan saat itu penggugat bernama Sang Dharma menggugat Pu Tabwel, saudara iparnya. Pu Tabwel digugat atas dasar hutang sebanyak 1 Suwarna Emas oleh istrinya yang bernama Si Campa yang telah meninggal dunia. Pu Tabwel dalam persidangan bersaksi bahwa hutang yang dilakukan oleh istrinya sama sekala tanpa sepengetahuannya. Bukti-bukti tentang keterkaitan Pu Tabwel dengan perkara hutang antara Sang Dharma dan Si campa baik berupa dokumen maupun kesaksian para saksi tidak dapat dihadirkan dalam persidangan. Dilain pihak, penggugat tidak hadir untuk memberikan sanggahan apapun terkait kesaksian Pu Tabwel. Karena kesaksian Pu Tabwel tidak dapat terbantahkan, maka pihak pengadilan yang dipimpin oleh Samgat Pinapan mengeluarkan keputusan bahwa Pu Tabwel tidak terlibat dan tidak perlu untuk membayar hutang pada Sang Dharma.

Sesuai dengan konten yang tercantum dalam Prasasti Guntur, dapat diketahui mengenai proses pengadilan di masa Raja Balitung. Suatu rumusan mengenai mekanisme peradilan di era Raja Balitung dapat dirumuskan menjadi sebagai berikut

"Peradilan diawali dengan proses pendaftaran perkara, dalam hal ini pihak penggugat melaporkan pihak yang tergugat kepada pejabat setempat atau si penguasa tertinggi di wilayah dia berada. Peradilan di Jawa Kuno memiliki tingkatan-tingkatan. Untuk perkara utang piutang, persidangan dilakukan oleh penguasa wilayah setingkat watak dan perkara yang lebih penting seperti perkara sengketa tanah, persidangan dilakukan oleh sang raja penguasa kerajaan. Terlihat bahwa tingkatan perkara juga menentukan apakah persidangan perlu digelar di tingkat watak atau tingkat kerajaan, makin berat perkara yang dipertentangkan maka memerlukan tingkatan pengadilan yang lebih tinggi. Kemudian, strata sosial orang yang berperkara juga menentukan tingkatan pengadilan. Penggugat dan tergugat yang merupakan rakyat biasa ditangani oleh pejabat watak. Sedangkan jika tergugat dan penggugat adalah pejabat, baik itu pejabat watak maupun pejabat kerajaan maka pengadilan ditangani oleh raja (Nugroho, Wuryani, \& Sunardi, 2018: 75-77)." 
Strata sosial memang tidak menjadi halangan bagi semua pihak untuk memperoleh keadilan, akan tetapi strata sosial tetap mempengaruhi tingkatan pengadilan yang akan mengadili. Semakin tinggi strata sosial orang yang berperkara maka semakin tinggi pula tingkatan pengadilan yang menyelenggarakan peradilan.

Sifat dari putusan pengadilan Jawa kuno adalah mutlak, walau begitu masih terbuka kemungkinan untuk ditinjau ulang selama masih ada bukti kuat dan alasan yang dapat dihadirkan oleh penggugat. Untuk mengungkap kebenaran dilakukan dengan suatu mekanisme, setiap pihak dalam persidangan baik penggugat maupun tergugat wajib melaksanakan pembuktian dalam persidangan. Menurut Boechari (2012: 192) ada tiga proses pembuktian dalam pengadilan Jawa Kuno, dikenal dengan sebutan Triprangama. Proses ini terdiri dari sakshi, likhita, dan bhukti. Sakshi merupakan orang-orang yang dapat menceritakan/menyaksikan mengenai kebenaran dari salah satu pihak, dapat sebagai saksi yang melihat langsung kebenarannya juga dapat sebagai saksi ahli yang benar-benar faham akan hal yang diperkarakan, sakshi memiliki kekuatan hukum terlemah, sedangkan likhita adalah surat-surat tertulis yang menguatkan pernyataan salah satu pihak, dan bhukti adalah bukti de facto yang memiliki kekuatan hukum tertinggi. Setiap orang yang dinilai memiliki nilai pembuktian terkuat maka akan dinyatakan sebagai pemenang perkara, tidak peduli apapun jabatannya (Nugroho, 2019).

Hingga di masa kini, sistem pembuktian dalam pengadilan masih relevan dan digunakan dalam pengadilan. Hakim tidak dapat memutuskan vonis pengadilan secara sepihak tanpa melihat menimbang bukti-bukti yang dihadirkan. Di masa lampau raja atau penguasa wilayah bersikap adil untuk memutus hasil pengadilan sesuai bukti-bukti dan saksi yang dihadirkan. Seharusnya hingga masa kini para pengadil tetap memegang prinsip peradilan yang adil tanpa pandang bulu seperti pada masa Jawa Kuno, kebenaran harus ditegakkan tanpa memandang jabatan maupun status sosial.

\section{PENANAMAN KONSEPSI TRIPRANGAMA DALAM PEMBELAJARAN}

Untuk meningkatkan kesadaran hukum bagi peserta didik tingkat Sekolah Menengah Pertama dalam konteks pembelajaran IPS, penulis menyusun sutu konsep desain pembelajaran IPS dengan materi tentang Pengadilan Jawa Kuno di era Raja Balitung yang tertuang dalam Prasasti Guntur. Materi tentang Raja Balitung, penguasa Mataram Kuno merupakan salah satu materi berkaitan dengan kehidupan masyarakat Nusantara pada masa berkembangnya kerajaan-kerajaan HinduBudha. Terkait dengan pembelajaran IPS di SMP, materi ini merupakan bagian dari materi pembelajaran pada kelas VII dalam KD 3.4 yang berisikan "memahami berfikir kronologi, perubahan dan kesinambungan dalam kehidupan bangsa Indonesia pada aspek politik, sosial, budaya, geografis, dan pendidikan sejak masa praaksara sampai masa hindu-budha, dan islam". Kemudian KD 4.4 yang berisikan "menyajikan hasil telaah tentang peninggalan kehidupan bangsa Indonesia 
pada aspek politik, sosial, budaya, geografis, dan pendidikan sejak masa praaksara sampai masa Hindu-Budha, dan Islam" (Kemendikbud, 2018).

Kegiatan pembelajaran selalu diawali dengan kegiatan menyusun desain pembelajaran/rencana pembelajaran. Desain/rencana pembelajaran dituangkan dalam bentuk Rencana Pelaksanaan Pembelajaran (RPP). Penyusunan RPP selalu dimulai dari analisa terhadap Kompetensi Dasar kemudian penjabaran kedalam Indikator Pencapaian Kompetensi (IPK). Setelah penyusunan IPK, kemudian akan dirumuskan mengenai tujuan pembelajaran, bahan ajar, model pembelajaran, hingga media apa yang akan digunakan, dan terakhir adalah komponen evaluasi pembelajaran.

Merujuk kembali pada KD baik 3.4 maupun 4.4, setelah dianalisis dapat dirumuskan beberapa IPK, yaitu:

3.4.1 Menganalisa aspek politik kehidupan Bangsa Indonesia masa Praaksara, sampai masa Hindu Budha, dan Islam

3.4.2 Mengidentifikasi aspek sosial kehidupan Bangsa Indonesia masa Praaksara, sampai masa Hindu Budha, dan Islam

3.4.3 Mengidentifikasi aspek budaya kehidupan Bangsa Indonesia masa Praaksara, sampai masa Hindu Budha, dan Islam

3.4.4 Menggambarkan aspek geografis kehidupan Bangsa Indonesia masa Praaksara, sampai masa Hindu Budha, dan Islam

3.4.5 Mendeskripsikan aspek pendidikan kehidupan Bangsa Indonesia masa Praaksara, sampai masa Hindu Budha, dan Islam

4.4.1 Menceritakan kembali hasil telaah kehidupan Bangsa Indonesia masa Praaksara, sampai masa Hindu Budha, dan Islam

Berfokus pada IPK 3.4.1 maka materi dalam pembelajaran yang dapat digunakan untuk menanamkan konsepsi Triprangama adalah "perubahan dan kesinambungan masyarakat Indonesia pada masa hindu budha secara kronologis", dengan pengayaan materi didalamnya mengenai konsep Triprangama di Kerajaan Mataram Kuno pada masa pemerintahan Raja Balitung. Berkaitan dengan materi, materi tersebut harus disiapkan tersendiri oleh pendidik disesuaikan dengan sarana prasarana yang tersedia di lingkungan belajar. Paling tidak pendidik harus dapat menampilkan beberapa konten yang cukup vital, yaitu: gambar Prasasti Guntur, hasil transliterasi Prasasti Guntur, hasil terjemahan Prasasti Guntur, narasi mengenai kisah yang terjadi dalam Prasasti Guntur. Akan sangat baik apabila materi dapat disiapkan dalam bentuk digital seperti: aplikasi Android, presentasi Power Point, video narasi, foto, gambar, atau audio narasi. Namun apabila tidak memungkinkan, paling tidak pendidik harus menyediakan print out gambar prasasti, hasil transliterasi, hasil terjemahan, narasi peristiwa. Akan lebih baik jika pendidik dapat menyediakan lebih dari satu jenis media agar dapat mengakomodir berbagai macam gaya belajar peserta didik. 
Kembali lagi perlu diingat, bahwa paradigma yang digunakan adalah menggunakan pedagogi reflektif, sehingga sintaks-sintaks model pembelajaran yang akan diterapkan adalah sintaks-sintaks dalam pedagogi reflektif. Sintaks-sintaks tersebut adalah: konteks, pengalaman, refleksi, aksi, evaluasi. Pembelajaran dimulai dengan memberikan konteks yang merupakan titik tolak awal berupa keadaan nyata peserta didik saat ini. Dalam tahapan ini peserta didik akan dibawa untuk menyelami kehidupan sehari-harinya, apakah dalam kehidupan sehari-hari peserta didik dan orang disekitarnya sudah selalu menaati peraturan atau hukum yang berlaku mulai dari tingkatan terkecil seperti aturanaturan yang ada di rumah untuk merapikan tempat tidur saat bangun, atau berangkat sekolah tepat waktu, tidak membolos, dan sebagainya. Kemudian tahap selanjutnya peserta didik diberikan pengalaman belajar berupa pemberian materi yang telah disiapkan oleh pendidik. Peserta didik akan dihadapkan pada pengalaman baru tentang pengetahuan bagaimana seharusnya aturan diikuti dan apa konsekuensi jika aturan dilanggar. Peserta didik akan diberi kebebasan untuk memaknai tentang konsekuensi dari suatu aturan supaya peserta didik dapat mengalami "interaksi" terhadap materi sehingga materi tersebut akan menjadi bermakna. Selanjutnya pendidik akan memberikan pertanyaan-pertanyaan yang akan menggugah kesadaran peserta didik tentang hukum. Melalui pertanyaan yang diajukan seperti: "apa makna dari kisah dalam prasasti?", "apakah jika kita melanggar aturan, kita perlu dihukum berat?", "apa sealanjutnya yang akan kita lakukan setelah menyadari bahwa taat hukum itu penting?", diharap peserta didik mampu untuk merefleksikan materi kedalam kehidupan sehari-harinya. Pada tahap ini peserta didik mulai untuk mengambil makna dan nilai-nilai dari narasi sejarah yang telah disajikan sebelumnya. Kemudian peserta didik menjalani tahap aksi, tahapan ini dilalui dengan memberikan pengalaman kepada peserta didik untuk mengkomunikasikan hal-hal positif yang telah didapatkan dalam tahapan refleksi. Pada tahap ini nilai-nilai mengenai kesadaran hukum diharapkan sudah tertanam dengan baik dalam diri peserta didik. Untuk mengetahui apakah proses pembelajaran ini efektif atau tidak, selanjutnya dilakukan suatu evaluasi secara komprehensif dalam semua aspek, baik itu affektif, kognitif, maupun psikomotorik. Khusus untuk menilai apakah proses pembelajaran telah berhasil meningkatkan kesadaran hukum peserta didik, maka dilakukan evaluasi menggunakan instrument kuisioner. Peserta didik akan diminta untuk mengisi kuisioner yang disiapkan oleh pendidik, kemudian akan dinilai apakah pembelajaran sudah efektif untuk meningkatkan kesadaran hukum, jika masih ada yang kurang maka akan dilakukan perbaikan untuk kegiatan dikemudian hari. Untuk peserta didik yang belum mengalami peningkatan kesadaran hukum akan dilakukan pembinaan untuk peserta didik dapat meningkatkan kesadaran hukumnya.

\section{SIMPULAN}

Kesadaran hukum menjadi suatu nilai yang sangat penting untuk dimiliki seorang warga negara. Dengan adanya kesadaran hukum yang baik, pranata hukum dan sosial di suatu negara akan menjadi lebih baik. Tentunya hal ini dapat menjadi kunci untuk mencapai kemajuan suatu negara. Pendidikan menjadi suatu proses dimana nilai-nilai dapat ditanamkan melalui serangkaian pengalaman belajar. Melalui pengalaman belajar inilah para peserta didik diharap dapat menemukan 
sendiri makna dari pentingnya kesadaran hukum untuk kehidupan sehari-harinya. Sebagai upaya untuk menanamkan kesadaran hukum, makan dilakukan penanaman nilai-nilai kesadaran hukum yang tersirat di dalam Prasasti Guntur yang memuat Konsepsi Triprangama. Konsepsi ini diintegrasikan kedalam pembelajaran IPS dengan menggunakan pendekatan Pedagogi Reflektif. Langkah-langkah dalam pembelajaran IPS dengan pendekatan Pedagogi Reflektif adalah meliputi: (1) Konteks, (2) Pengalaman, (3) Refleksi, (4) Aksi, (5) Evaluasi.

Melalui langkah-langkah tersebut peserta didik diajak untuk menyelami konten dalam Prasasti Guntur tentang konsepsi Triprangama, merefleksikan kedalam kehidupan sehari-hari, mengambil makna dari peristiwa yang tertulis dalam prasasti, kemudian diharapkan kesadaran hukum dari peserta didik akan dapat ditingkatkan.Melalui tertanamnya karakter dan nilai-nilai sadar hukum dalam dri peserta didik, diharapkan mereka akan dapat menjadi agen perubahan di masa yang akan datang untuk membawa angin perubahan di negeri Indonesia menuju kearah yang lebih baik.

\section{DAFTAR RUJUKAN}

Boechari. (2012). Melacak Sejarah Indonesia Kuno Lewat Prasasti: Kumpulan Tulisan Boechari. Jakarta: Kepustakaan Populer Gramedia.

Duminiuco, V. (2000). The Jesuit Ratio Studiorum: 400th Anniversary Perspective. New York: Fordham University Press.

Kemendikbud. Lampiran Permendikbud RI Nomor 37 Tahun 2018 Tentang Perubahan Atas Permendikbud RI Nomor 24 Tahun 2016 Tentang Kompetensi Inti dan Kompetensi Dasar Pelajaran Pada Kurikulum 2013 Pada Pendidikan Dasar Menengah. , (2018).

Kenedi, J. (2015). Studi Analisis Terhadap Nilai-Nilai Kesadaran Hukum Dalam Pendidikan Kewarganegaraan (Civic Education) di Perguruan Tinggi Islam. Madania, 19(2).

McGuire, L., Lay, K., \& Peters, J. (2009). Pedagogy of Reflective Writing in Professional Education. Journal of the Science of Teaching and Learning, 9(1), 93-107.

Nugroho, L. A. (2019). Balitung "Sang Penguasa": Sebuah Kajian Epigrafi. Universitas Kristen Satya Wacana.

Nugroho, L. A., Wuryani, E., \& Sunardi. (2018). Kebijakan Penguasa Jawa Kuno: Balitung Dalam Sebuah Kajian Epigrafi. Jurnal Cakrawala, 7(1).

Pousson, J. M., \& Myers, K. A. (2018). Ignatian Pedagogy as a Frame for Universal Design in College: Meeting Learning Needs of Generation Z. Education Sciences, 8(193), 1-10.

Qodir, A. (2017). Teori Belajar Humanistik Dalam Meningkatkan Prestasi Belajar Siswa. Jurnal Pedagogik, 4(2), 188-202.

Reardon, B. A., \& Snauwaert, D. T. (2011). Reflective Pedagogy, Cosmopolitanism, and Critical Peace Education For Political Efficacy: A Discussion of Betty A. Reardon's Assessment of the Field. In Factis Pax Journal Of Peace Education and Social Justice, 5(1), 1-14. 
Rocheleau, J. (2004). Theoretical Roots of Service-Learning: Progressive Education and the Development of Citizenship. In B. Speck \& S. Hoppe (Eds.), Service-Learning: history, Theory, and Issues (pp. 3-22). Westport: Praeger Publisher.

Rochmawat, I. (2017). Pendidikan Karakter Dalam Kajian Filsafat Nilai. Jurnal Pendidikan Islam, 3(1), $36-47$.

Rosana, E. (2014). Kepatuhan Hukum Sebagai Wujud Kesadaran Hukum Masyarakat. Jurnal TAPIs, 10(1).

Sariyatun, Joebagio, H., \& Akhyar, M. (2018). Teacher's Perception on Digital Teaching Material Development in Social Science Education. Journal Of Turkish Science Education, 15(special), 13-21.

Sekretariat Negara Republik Indonesia. Peraturan Presiden Republik Indonesia Nomor 87 Tahun 2017 Tentang Penguatan Pendidikan Karakter. , (2017).

Subagya. (2010). Paradigma Pedagogi Reflektif. Mendampingi Peserta Didik Menjadi Cerdas dan Berkarakter (Terjemahan). Yogyakarta: Penerbit Kanisius.

Suparno, P. (2015). Pembelajaran di Perguruan Tinggi Bergaya Paradigma Pedagogi Refleksi (PPR). Yogyakarta: Kanisius.

Syaputra, E., \& Sariyatun. (2020). Model dan Materi Pembelajaran IPS Dalam Bingkai Pendidikan Abad 21: Sebuah Telaah Teoritis. Diakronika, (Juni).

Widja, I. G. (2002). Menuju Wajah Baru Pendidikan Sejarah. Yogyakarta: Lapera Pustaka Utama. 